\title{
FAKTOR-FAKTOR YANG MEMPENGARUHI KESELARASAN KELUARGA BAGI WANITA BEKERJA DI BEBERAPA UNIVERSITAS DI YOGYAKARTA
}

\author{
Nuryati \\ Pendidikan Pancasila dan Kewarganegaraan Universitas Cokroaminoto Yogyakarta \\ Jl. Perintis Kemerdekaan, Gambiran, Pandeyan, Umbulharjo, Kota Yogyakarta 55161 \\ Email: nuryatikip@gmail.com
}

\begin{abstract}
ABSTRAK
Penelitian ini bertujuan untuk mengungkapkan faktor-faktor yang mempengaruhi keselarasan keluarga bagi wanita yang bekerja di beberapa universitas di Yogyakarta.

Jenis penelitian ini termasuk penelitian survai. Populasi penelitian ini sejumlah 280 wanita yang bekerja di enam universitas di Yogyakarta, yakni: Universitas Ahmad Dahian, Universitas Cokroaminoto, Universitas Negeri Yogyakarta, Universitas Prokiamasi, Universitas PGRI, dan Universitas Widya Mataram. Penentuan sampel sejumlah 120 responden yang ditentukan melalui formula Cohen, dengan pengambilan sampel responden dan enam universitas di Yogyakarta menggunakan teknik proportional random sampling. Teknik pengumpulan data menggunakan model skala Likert dan analisisnya menggunakan analisis deskriptif, uji regresi, dan uji regresi ganda. Menentukan persyaratan analisis regresi dianalisis dengan uji normalitas, lineantas, multikolineantas, dan homosedatisitas.

Hasil analisis deskriptif mengungkapkan, bahwa: keselarasan keluarga bagi wanita yang bekerja masuk pada kategori cukup baik; latar belakang pendidikan wanita yang bekerja masuk pada kategon pendidikan yang tinggi; pendapatan wanita yang bekerja masuk pada kategori pengahasilan yang besar; dan manajemen waktu bagi wanita bekerja masuk pada kategori cukup disiplin. Hasil analisis regresi menunjukkan bahwa: (1) Latar beiakang pendidikan wanita yang bekerja berpengaruh secara signifikan terhadap keselarasan keluarga $(\beta=0,227 ; \mathrm{p}=0,027<0,05)$. (2) Pendapatan wanita bekerja berpengaruh secara signifikan terhadap keselarasan keluarga $\left(\beta_{2}=\right.$ 0,$212 ; \mathrm{p}=0,040<0,05$ ). (3) Manajemen waktu wanita yang bekerja berpengaruh secara signifikan terhadap keselarasan keluarga $\left(\beta_{3}=0,419 ; \mathrm{p}=0,000<0,05\right)$. Hasil analisis regresi ganda menunjukkan terdapat pengarah yang signifikan secara bersama-sama antara variabel latar belakang pendidikan, pendapat wanita bekerja, dan manajemen waktu terhadap keselarasan keluarga $\left(\mathrm{R}_{\mathrm{y}, 123}=\right.$ 0,624; $\mathrm{F}=24,693 ; \mathrm{p}=0,000<0,05)$ dengan besarnya kontribusi sebesar 39\%. Dengan demikian, dapat disimpulkan bahwa latar beiakang pendidikan, pendapat wanita bekerja, dan manajemen waktu dapat mempengaruhi terhadap keselarasan keluarga bagi wanita yang bekerja di universitas di Yogyakarta.
\end{abstract}

Kata Kunci: Keselarasan keluarga, wanita bekerja

\section{PENDAHULUAN}

Kehidupan wanita dalam konteks keluarga, secara luas dari waktu ke waktu terus menunjukkan kemajuan. Kondisi yang demikian ini merupakan usaha kaum wanita, baik wanita yang belum menikah maupun yang sudah menikah. Wanita adalah mitra sejajar dengan pria, secara bersama-sama bertanggung jawab terhadap kepentingan keluarga. Namun sebagai kodratnya, berperan sebagai ibu rumah tangga. 
Keterlibatan wanita bekerja untuk mendapatkan tambahan pendapatan nafkah. Oleh karena itu, beban tugas wanita semakin berat di satu sisi harus mengerjakan pekerjaan rumah tangga, di sisi lain bekerja di luar rumah. Berdasarkan data EPS yang diproyeksikan pada tahun 1998, angkatan kerja perempuan akan terus meningkat hingga 40,2\% atau hampir sejajar dengan angkatan kerja laki-laki. Proyeksi angkatan kerja tahun 1998-2000, bahwa sektor angkatan kerja yang dimasuki perempuan diantaranya menjadi buruh $38,8 \%$ dan $100 \%$ dan self employment (pedagang kecil, industri rumah tangga dan sebagainya) $40 \%$ dan total $100 \%$ semua angkatan kerja (http://www.akatiga.or.id).

Berdasarkan data di atas, banyak kaum wanita yang bekerja selain sebagai ibu rumah tangga. Kaum wanita yang bekerja di luar rumah sering tidak dapat menunaikan tugasnya secara maksimal dalam mengurus rumah tangganya, tetapi tetap harus men-gutarnakan perannya sebagai ibu rumah tangga. Wanita dalam kehidupan berkeluarga berkeinginan untuk mencapai keberhasilan dan sekaligus dapat membahagiakan seluruh anggota keluarganya, dengan cara menerapkan kerja tim yang ciri-cirinya adalah kekompakan, pembagian kepemimpinan, serta adanya saling percaya dan menghormati.

Kenyataannya di dalam fenomena sosial masih banyak keluarga yang membedakan peran berdasarkan jenis kelamin dalam keluarga, peran wanita dalam keluarga sebagai pengelola yang harus mampu mengelola hubungan individu dan pengembangan keluarga. Secara riel, bahwa wanita sebenamya potensial berperan di bidang apa saja termasuk di bidang bela negara, mengisi kemerdekaan dengan berbagai penemuan ilmu baru, mencapai terobosan jitu agar Indonesia dapat keluar dan krisis multidimensi, akan tetapi tetap bertanggung jawab atas peranannya yang tidak dapat didelegasikan yakni mengandung, melahirkan, dan menyusui. Tap MPR No. 11/1983 menyatakan, wanita wajib berperan ikut mewujudkan keluarga sejahtera dan pembinaan terhadap generasi mudanya.

Keterlibatan peranan para wanita dalam bekerja karena harus ikut menanggung ekonomi keluarga, baik sebagai penambah pendapatan maupun sebagai pencari nafkah utama. Oleh karena itu, beban tugas wanita semakin berat, di satu sisi harus mengerjakan pekerjaan rumah tangga di sisi lain juga bekerja di luar rumah. Kaum ibu yang bekerja di luar rumah sering tidak dapat menunaikan tugasnya secara maksimal dalam mengurus rumah tangganya. Demikian juga wanita karier, yang harus tetap mengutamakan perannya sebagai ibu rumah tangga dan tetap menyisihkan waktu untuk berkomunikasi dan melaksanakan pendidikan keluarga. Dengan demikian, maka dalam penelitian ini ingin mengungkapkan faktor-faktor yang mempengaruhi terhadap keselarasan dalam keluarga pada wanita yang bekerja.

Pada penelitian ini dan permasalahan yang akan diungkap mengenai deskripsi keselarasan keluarga bagi wanita yang bekerja di enam universitas di Yogyakarta. Menurut Murni (2000: 106), 
selaras adalah suasana yang mendorong terciptanya ketenteraman lahir dan batin. Kehidupan yang selaras berarti suasana kehidupan yang rukun, saling menghormati, saling menghargai, dan penuh toleransi. Begitu pula dengan Ihromi (1999: 67) mengungkapkan selaras di dalam berbagai keaktifan kerja adalah kebutuhan keluarga yang menjadikan urusan pekerjaan di luar rumah dan dapat dipadukan secara harmonis di dalam rumah tangga. Permasalahan keselarasan ini, bukanlah hal yang sederhana sebab membutuhkan kemauan keras, kemampuan intelektual, ketahanan mental, kemampuan mengendalikan diri, terampil membagi waktu dan punya kesanggupan untuk belajar dan penuh toleransi, di mana keselarasan ini sangat menjadi kebutuhan keluarga untuk menjadikan keluarga yang harmonis terhindar dan pertengkaran.

Menurut HR. Bukhori (1999: 26), suasana selaras atau harmonis di dalam keluarga perlu sekali adanya rasa tanggung jawab dan saling keterbukaan. Rasa tanggung jawab istri harus juga dirasakan sebagai tanggung jawab suami dalam keluarga. Kerjasama istri dan suami dalam keluarga adalah bagaimana menangani kepentingan pribadi, urusan rumah tangga, dan kepemimpinan keluarga, yang semuanya itu harus memiliki rasa pengendalian diri atau didiskusikan melalui musyawarah intern keluarga. Dengan adanya musyawarah dan introspeksi akan lahir prinsip asah, asih, dan asuh tidak ada eksploitasi atau tindak kekerasan di dalam keluarga, apalagi saling mengandalkan.

Melalui kerjasaina antara istri dan suami yang memiliki rasa tanggung jawab introspeksi diri dan selalu bermusyawarah dalam pemecahan masalah, akan memunculkan keberhasilan dalam keluarga. Keluarga yang berhasil juga keluarga yang terhormat secara moral dan material di mata masyarakat, sebab mampu memegang teguh tata nilai dan norma yang berlaku dalam kehidupan bersama di masyarakat. Selain itu penelitian ini juga mengungkap pengaruh latar belakang pendidikan wanita yang bekerja terhadap keselarasan keluarga di enam universitas di Yogyakarta.

Latar belakang wanita yang berkerja dalam penelitian ini dilihat dari tingkat pendidikan. Menurut Undang-Undang Republik Indonesia Nomor 20 Tahun 2003 tentang Sistem Pendidikan Nasional menguraikan, bahwa pendidikan adalah usaha untuk menyiapkan peserta didik melalui kegialan bimbingan, pengajaran, dan/atau latihan bagi peranannya di masa yang akan datang. Saidihardjo (1997:5) mengatakan, pendidikan adalah pembentukan watak, mental, memperbaiki nilai-nilai moral-etik, dan peningkatan intelektual dalam masyarakat. Di samping itu pula, pendidikan membentuk perkembangan karakter dan peningkatan kecerdasan emosional, yang didapatkan melalui tahapan jenjang pendidikan, mulai dan Taman Kanak-Kanak, Sekolah Dasar, SMP/ MTs, SMA/ MA dan Perguruan Tinggi.

Jenjang pendidikan adalah suatu tahap dalam pendidikan berkelanjutan ditetapkan berdasarkan tingkat perkembangan para peserta didik serta kelulusan dan kedalaman bahan pengajaran (http://www.dikti.org/peraturan.htm). Menurut Irsyad Syafar Buan (Jurnal OASE, 2000 
yang diambil pada tanggal 01 Juni 2003, dan http://jurnal/ tentang.oase/isnet.org/pdk.htm), jenjang pendidikan (educational ladder) yaitu tangga atau tingkat yang harus dilalui seseorang dengan menggeluti pendidikan secara berturut-turut, dengan sistem yang memiliki permulaan terbatas, kemudian ke tingkat lanjut yang terbatas dan ujung yang terbatas pula. Seperti rnulai dan Sekolah Dasar, SLTP, SLTA, hingga sampai ke Perguruan Tinggi, berakhir pada suatu titik (puncak tangga) atau mengalami discountinue, dikarenakan faktor usia yang menua atau tua.

Pada penelitian ini juga mengungkapkan pengaruh pendapatan bagi wanita yang bekerja terhadap keselarasan keluarga di enam universitas di Yogyakarta. Menurut Badan Pusat Statistik (EPS) tahun 2003, pendapatan adalah penghasilan dari hasil usaha yang diukur dalam satuan rapiah. Kemudian, diterangkan lebih jelas lagi oleh Sudibia (1985: 20), penghasilan adalah besarnya nilai uang dan barang yang dibawa pulang untuk keluarganya dalam bentuk uang. Menurut Hadisupadmo (1988: 103), masalah pendapatan ramah tangga tidak terlepas dari banyaknya anggota ramah tangga yang bekerja dan jumlah tanggungan keluarga serta sumber pendapatan yang pada akhirnya akan dapat mempengaruhi pendapatan perkapita anggota rumah tangga. Kemudian, yang terakhir pada penelitian juga mengungkapkan pengarah manajemen waktu terhadap keselarasan keluarga bagi wanita yang bekerja di enam universitas di Yogyakarta.

Timpe (1991: 70) mengungkapkan, waktu adalah sumber daya yang utama, dan uniknya setiap orang memilikinya dalam jumlah yang sama, dan waktu tersebut tidak dapat dibeli karena setiap pekerjaan memakan waktu yang panjang. Mengefisiensikan waktu pekerjaan sebagaimana memanajemenkan keseluruhan pekerjaan dengan baik, menurut Terry dijelaskan bahwa pengelolaan pekerjaan terdiri dari fungsi pengelolaan perencanaan, pengorganisasian, pemulai dan pengendalian, serta dapat memanajemenkan pengelolaan waktu yang ditempatkan dalam fungsi pengendalian. Berpijak dari pendapat tersebut, waktu berpengaruh pada manusia termasuk bagi wanita yang berkeluarga dan bekerja harus dapat merencanakan penggunaan waktu. Pengelolaan waktu merupakan suatu proses yang terdiri dari fungsi perencanaan, pengorganisasian dan pengendalian. Jadi untuk memanajemenkan pekerjaan oleh wanita berkeluarga dapat rnembawa perubahan yang tidak diinginkan misalnya timbul pertengkaran, ketegangan dalam keluarga karena adanya konflik keluarga yang tidak terselesaikan. Di samping itu pula, selain adanya pengelolaan waktu bagi wanita bekerja dan bekeluarga perlu adanya perencanaan strategis yang layak dibakukan dalam pekerjaan ataupun di dalam rumah tangga, di mana perencanaan strategis yang dikatakan oleh Bryson's dalam Strategic Planning in Public and Nonprofit Organizations:

Strategic planning adalah suatu manajemen yang digunakan untuk membantu suatu organisasi atau pekerjaan agar lebih baik bekerja ke arah dan tujuan yang sarna. Ringkasnya, perencanaan strategis adalah suatu usaha yang mengatur untuk menghasilkan keputusan pokok yang membentuk suatu perencanaan organisasi, seperti, apa dan mengapa perencanaan strategi dilakukan, semuanya itu adalah demi kesinambungan kemudahan pekerjaan di masa yang akan datang. 
Perencanaan strategis ini gunanya untuk memanajemenkan program kerja yang baku agar semua pekerjaan dapat berjalan dengan lancar dan terkendali, sehingga tidak menimbulkan adanya konflik dalam rumah tangga atau keluarga dan dapat membedakan mana pekerjaan dan pekerjaan di rumah tangga.

\section{METODE PENELITIAN}

Lokasi Penelitian ini dilaksanakan di universitas yang ada di Yogyakarta. Lokasi yang menjadi objek penelitian diambil enam universitas, dengan alasan bahwa keenam universitas tersebut berdasarkan hasil undian dan karyawan administrasi, ternyata yang lebih mendominasi wanita yang bekerja sebagai tenaga kerjanya administrasi, yaitu; 1) Universitas Ahmad Dahlan, 2) Universitas Cokroaminoto, 3) Universitas Negeri Yogyakarta, 4) Universitas Proklamasi, 5) Universitas PGRI Yogyakarta, dan 6) Uni versitas Widya Mataram. Waktu penelitian dilaksanakan pada bulan Desember 2003 sampai bulan Agustus 2004.

Jenis penelitian ini termasuk penelitian survai. Penelitian survai adalah penelitian yang mengambil sampel dan satu papulasi dengan menggunakan kuesioner sebagai alat pengumpul data yang pokok (Masri \& Effendi 1995: 3). Sampel responden pada penelitian ini sejumlah 120 wanita yang bekerja di enam Universitas di Yogyakarta. Teknik analisis data ini menggunakan analisis deskriptif, uji persyaratan regresi, uji regresi dan uji regresi ganda. Dengan demikian, teknik analisis ini dapat dijelaskan sebagai berikut: Analisa Deskriptif, analisis regresi sederhana, regresi ganda dan korelasi ganda serta mengetahui signifikansinya dengan uji $\mathrm{F}$ yang didasarkan atas pendekatan analisis varians pada taraf signifikansi 5\% atau $\mathrm{p}<0,05$.

\section{PEMBAHASAN}

Deskripsi profil wanita yang berkeluarga dan bekerja di enam universitas di Yogyakarta ratarata wanita berkeluarga yang bekerja di universitas/kantor memiliki keselarasan yang baik dalam berkeluarga. Hal ini di peroleh dari hasil persentase pernyataan tentang aspek keselarasan keluarga yang menyatakan, bahwa profil wanita yang sudah bekeluarga tetap selalu menjaga keutuhan dan keharmonisan dalam keluarga. Hasil pemilihan pemyataan tersebut memberikan tanggapan bahwa kaum ibu di dalam rumah tangganya memiliki peranan yang besar yang haras mampu menjaga keselarasan keluarganya dengan penuh tanggung jawab. Dengan demikian dapat dipahami bahwa keselarasan keluarga merupakan keharmonisan dan keutuhan di dalam rumah tangga yang terjalin adanya saling terbuka jika ada pemasalahan, terjalin adanya komunikasi aktif, saling mendukung, dapat membedakan pekerjaan di kantor atau di rumah, selalu bermusyawarah untuk memecahkan permasalahan. 
Hasil pemilihan penyataan tentang aspek keterbukaan sekitar $69 \%$ yang menyatakan, kaum wanita yang berkeluarga dan bekerja selalu terbuka mengenai permasalahan dan pekerjaan apa pun di dalam rumah tangganya dan tidak pernah disembunyikan, hal ini dilakukan dengan baik dan senang hati. Hasil pemilihan dan $69 \%$ ini, ternyata rata-rata wanita yang berkeluarga dan bekerja untuk menjaga keharmonisan keluarga di antaranya selalu meminta pendapatnya kepada suami apa bila ada permasalahan di kantor atau di dalam keluarganya, dapat mengendalikan emosi untuk selalu terbuka mengasuh dan mendidik anak-anaknya, meminta ijin dan menyebutkan tujuannya kepada suami ketika hendak keluar rumah, berekreasi bersama suami dan anak-anak jika pada saatsaat libur sekolah, dan sebagainya.

Hasil pemilihan pernyataan dan aspek komunikasi aktif sekitar 66\% yang me-nyatakan, wanita berkeluarga yang sudah bekerja untuk menjaga keutuhan rumah tangganya selalu terjalin adanya komunikasi aktif di dalam keluarga, yang terpenting sekali dengan suami. Hasil pemilihan dari $66 \%$ tersebut ternyata rata-rata wanita berkeluarga yang sudah bekerja dalam menjaga keharmomsan keluarga seorang ibu selalu bermusyawarah untuk menyelesaikan problem keluarga dengan baik, selalu adanya dialog dengan suami untuk meminta pendapatnya dalam permasalahan keluarga atau pekerjaanya, dan sebagainya.

Hasil pemilihan pernyataan dan aspek dukungan keluarga sekitar 50\% yang menyatakan, wanita berkeluarga yang sudah bekerja kadang-kadang atau tidak selalu mendapat dukungan dan keluarga untuk meningkatkan karier di pekerjaannya. Hasil pemilihan dan $50 \%$ tersebut, ternyata rata-rata wanita berkeluarga yang sudah bekerja dalam menjaga keutuhan keluarga yang selaras demi meningkatkan kesejahteraan yang lebih meningkat di dalam dukungan keluarga, di satu sisi keluarga mendukung untuk pengembangan karier di sisi lain dukungan keluarga masih meragukan. Hal ini disebabkan, karena banyak keluarga yang berantakan atau rumah tangganya tidak terurus akibat faktor kaum ibu hanya memikirkan karier atau pengembangan diri sendiri tanpa mempedulikan keluarga.

Hasil pemilihan pernyataan dari aspek membedakan permasalahan sekitar $75 \%$ yang menyatakan wanita berkeluarga yang bekerja di universitas dapat membedakan permasalahan di kantor dan di rumah tangga dengan baik. Perolehan hasil pemilihan $75 \%$ ini, ternyata rata-rata wanita berkeluarga yang bekerja demi menjaga keselarasan keluarga dalam rumah tangganya seorang Ibu harus berusaha semaksimal mungkin untuk tidak membawa urusan kantor ke rumah, hal ini sudah menjadi kebiasaan bagi kaum ibu untuk berusaha tidak pernah membawa urusan kantor dalam rumah tangganya, kemudian mengerjakan urusan pekerjaan kantor sebisa mungkin di kantor, lalu berusaha untuk tidak mencampuradukan antara pekerjaan kantor dan pekerjaan rumah, dan sebagainya. 
Hasil pemilihan pernyataan dan aspek pemecahan masalah sekitar 53\% yang menyatakan, wanita berkeluarga yang bekerja di universitas mampu memecahkan permasalahan keluarga untuk mendapatkan solusinya dengan baik. Perolehan hasil pemilihan $53 \%$ ini, ternyata rata-rata wanita berkeluarga yang bekerja untuk mempertahankan kestabilan keluarga, kaum Ibu harus bisa menangani permasalahan-permasalahan yang datang dari keluarga sendiri atau dari luar keluarga yang perlu ditanggapi dengan tegas dan tepat.

Hasil tersebut juga dapat dilihat dan perolehan nilai rerata terletak di atas skor tengah ideal 65,5, atau 65,5 < M. Bik dilihat dan hasil kecenderangan keselarasan keluarga memiliki kecenderungan yang cukup baik (36,67\%). Dengan demikian, keselarasan keluarga memiliki arti harmonis, sepadan, seimbang dan tidak ada perbedaan yang menyolok. Berdasarkan hasil penelitian di atas menyatakan bahwa keselarasan keluarga bagi wanita yang bekerja di universitas di lingkungan Yogyakarta cukup baik, hal ini terlihat dari kemampanan dan keuletan serta pembagian waktu kerja pada waktunya, secara riel wanita yang bekerja dapat membagi waktu dengan baik dan cermat serta mampu memegang teguh tata mlai dan norma yang berlaku dalam kehidupan bersama.

Deskripsi latar belakang pendidikan bagi wanita yang bekerja di universitas di Yogyakarta memiliki kecenderungan pendidikan yang tinggi. Hasil tersebut terlihat dan perolehan nilai mean $(18,80)$ terletak di atas rerata nilai tengah 17,5 , atau $17,5<\mathrm{M}$. Bila dilihat dari hasil kecenderungan latar belakang pendidikan bagi wanita yang bekerja di universitas di Yogyakata memiliki tingkat pendidikan yang tinggi $(44,17 \%)$. Dengan demikian, latar belakang pendidikan bagi wanita yang bekerja di enam universitas di Yogyakarta merapakan keharusan memiliki pendidikan yang tinggi yang sederajat dengan tingkat level perguruan tinggi. Wanita yang memiliki pendidikan tinggi dalam pekerjaan dapat mengerti dan memahami keselarasan dalam membangun lembaganya serta menumbuhkan keakraban dalam satu profesinya.

Hasil analisis regresi menunjukkan bahwa terdapat pengaruh yang signifikan latar belakang pendidikan bagi wanita yang bekerja terhadap keselarasan keluarga sebesar $\mathrm{t}=2,247$; $\mathrm{p}<0,05$. Dengan demikian dapat disimpulkan, bahwa terdapat pengaruh yang sangat signifikan latar belakang pendidikan bagi wanita yang bekerja terhadap keselarasan keluarga. Hasil tersebut menunjukkan bahwa pendidikan dengan jenjang pendidikan yang tinggi bagi wanita yang bekerja di universitas amatlah penting agar meningkatkan kualitas pemahaman dan pengetahuan terhadap lembaga pendidikan. Di samping itu pula, wanita yang memiliki jenjang pendidikan yang tinggi keberadaannya akan memahami arti dari keselarasan keluarga dalam rumah tangganya akan lebih mengerti dan tercipta kerukunan dalam kehidupan keluarga.

Deskripsi pendapatan bagi wanita yang bekerja di enam universitas di Yogyakarta, berkisar dari pendapatan terkecil Rp. 1.000.000 sampai nilai pendapatan terbesar Rp. 2.600.000, dengan rerata pendapatan Rp. $1.845,000$, berarti dapat dikatakan bahwa pendapatan bagi wanita yang 
bekerja di enam universitas di Yogyakarta termasuk golongan pendapatan pada kategori yang besar. Kecenderungan ubahan pendapatan bagi wanita yang bekerja dikategorikan menjadi 5 kategori, yaitu pendapatan sangat besar, besar, cukup, rendah, dan kurang.

Data yang dikumpulkan dan hasil persentase kecenderungan pendapatan bagi wanita yang bekerja di enam universitas di Yogyakarta rata-rata memiliki pendapatan yang besar tiap bulannya sekitar 40.00\% yang merasakan pendapatannya di antara Rp. 800.000 sampai Rp. 1.600.000. Pendapatan bagi wanita yang bekerja disesuaikan dengan keuletan, kerajinan, keterampilan, dan kedisiplinan dalam memegang amanat pekerjaannya pada profesinya. Dengan demikian dapat disimpulkan, bahwa pendapatan merupakan penunjang kehidupan dalam keluarga, rnelaiui pendapatan (upah) yang tinggi dapat menstabilkan perekonomian rumah tangga.

Hasil analisis regresi terdapat pengarah pendapatan bagi wanita yang bekerja di universitas di Yogyakarta terhadap keselarasan keluarga sebesar $\mathrm{t}=-2,081 ; \mathrm{p}<0,05$. Dengan demikian dapat disimpulkan, bahwa terdapat pengaruh yang signifikan pendapatan bagi wanita yang bekerja terhadap keselarasan keluarga. Hal ini membuktikan, bahwa wanita yang bekerja dengan baik dan disiplin akan mendapatkan upah yang sesuai dengan profesinya, sehingga dapat mewujudkan keharmonisan dalam keluarga.

Deskripsi manajemen waktu bagi wanita yang bekerja di universitas di Yogyakarta, di mana perolehan nilai mean $(53,86)$ lebih kecil dan rerata nilai tengah atau $\mathrm{M}<56,5$, sehingga dapat dikatakan bahwa manajemen waktu bagi wanita yang bekerja di enam universitas di Yogyakarta memiliki manajemen waktu yang cukup. Kecenderungan ubahan manajemen waktu bagi wanita yang bekerja dan data yang terkumpul rata-rata dalam memanajemenkan waktunya sangat cukup sekitar 34,17\% yang merasakan telah mengatur waktunya lebih efesien. Dengan demikian, manajemen waktu merupakan kedisiplinan tenaga kerja dalam kegiatan dan diukur penilaian kinerja melalui membandingkan kinerja pekerjaan dalam satu periode setiap akhir tahun.

Berdasarkan hasil penelitian di atas tentang manajemen waktu bagi wanita yang bekerja ternyata, wanita yang bekerja di enam universitas di lingkungan Yogyakarta memiliki manajemen kedisiplinan waktu yang cukup baik, hal ini tercermin dari hasil kinerja yang baik, cermat, terampil dan disiplin yang tinggi, sehingga dan memanajemenkan waktu untuk berdisiplin dapat mengatur keharmonisan keluarganya yang baik pula.

Hasil analisis regresi terdapat pengaruh manajemen waktu bagi wanita yang bekerja terhadap keselarasan keluarga di enam universitas di Yogyakarta sebesar $t=5,692 ; p<0,05$. Demikian dapat disimpulkan, bahwa terdapat pengaruh yang sangat signifikan manajemen waktu bagi wanita yang bekerja terhadap keselarasan keluarga. Hal ini membuktikan, bahwa menajemen yang baik bagi wanita yang bekerja dapat menumbuhkan perkembangan bagi instansinya serta dapat memberikan waktu untuk keharmomsan keluarga. 
Berdasarkan hasil analisis regresi ganda $R_{y i 23}=0,624$ dan harga $F$ regresi sebesar 24,693 di mana harga $p=0,000$ serta koefisien determinasi $R^{2}=0,390$. Berarti memiliki pengaruh yang sangat signifikan latar belakang pendidikan, pendapatan, dan manajemen waktu secara bersama-sama terhadap keselarasan keluarga bagi wanita yang bekerja di enam universitas di Yogyakarata. Hal ini membuktikan, bahwa keselarsan keluarga mempunyai arti penting bagi kehidupan rumah tangga, di samping itu pula pendidikan yang tinggi juga dapat memberikan pengertian dan pemahaman tentang keselarasan keluarga mengerti dan dapat memecahkan masalah-masalah daiam keluarga. Pendapatan yang tinggi juga menunjang adanya keharmonisan dalam kehidupan keluarga yang menunjang untuk pertumbuhan ekononai keluarga dan kebutuhan-kebutuhan yang lainnya, serta kedisiplinan yang tinggi dan pembagian dalam memanajemenkan waktu untuk keluarga dan kerja merupakan tingkat untuk memberikan kebahagian dalam berumah tangga.

Berdasarkan hasil tersebut di antara varibel keselarasan keluarga bagi wanita yang bekerja di universitas dapat dijelaskan oleh variabel latar belakang pendidikan pendapatan, dan manajemen waktu sebesar 39,00\%. Berarti 39\% ini menjelaskan, bahwa wanita berkeluarga sungguh-sungguh bertanggung jawab penuh untuk mendisiplinkan dirinya pada pekerjaan di kantor dan di rumah serta selalu mengharmoniskan rumah tangga di dalam mengurasi keluarganya.

\section{KESIMPULAN}

Kesimpulan pada penelitian ini adalah berdasarkan hasil data keselarasan keluarga memiliki tingkat kecenderangan keselarasan yang cukup baik sekitar 36,67\%, di dalam kehidupan keluarganya. Hal ini memberi makna, bahwa keselarasan keluarga memiliki arti harmonis, sepadan, seimbang dan tidak ada perbedaan yang mencolok. Berdasarkan hasil penelitian menyatakan bahwa keselarasan keluarga bagi wanita yang bekerja di enam universitas di Yogyakarta keharmomsan dan keuletan serta pembagian waktu kerja pada waktunya, secara riel wanita yang bekerja dapat rnembagi waktu dengan baik dan cermat serta mampu memegang teguh tata nilai dan norma yang berlaku dalam kehidupan bersama di kantor maupun di dalam keluarga.

Latar belakang pendidikan bagi wanita yang bekerja terhadap keselarasan keluarga, berdasarkan hasil uji analisis regresi membuktikan $0=0,227$; $=0,027<0,05$, bahwa latar belakang pendidikan bagi wanita yang bekerja memiliki pengaruh yang signifikan terhadap keselarasan keluarga. Menyatakan bahwa keselarasan keluarga dapat dijelaskan oleh latar belakang pendidikan wanita yang bekerja di enam universitas di Yogyakarta. Latar belakang pendidikan wanita yang pendidikannya tinggi mendukung terlaksananya keselarasan yang ada di instansi ataupun yang ada di keluarga untuk menghindari adanya kecemburuan sosial, maka semakin tinggi tingkat pendidikan wanita yang bekerja di lingkungan universitas di Yogyakarta akan memahami pengertian 
keselarasan dalam keluarganya serta semakin tinggi pula tingkat keharmonisan terhadap lingkungan di kantor ataupun di dalam rumah tangganya.

Pendapatan bagi wanita yang bekerja terhadap keselarasan keluarga, berdasarkan uji regresi raembuktikan $\beta_{2}=0,212 ; p=0,040<0,05$, bahwa pendapatan bagi wanita yang bekerja memiliki pengaruh yang signifikan terhadap keselarasan keluarga. Menyatakan bahwa keselarasan keluarga dapat dijelaskan oleh pendapatan bagi wanita yang bekerja di universitas di Yogyakarta. Pendapatan penghasilan yang besar mendukung terciptanya suasana keharmonisan di dalam interaksi terhadap kehidupan keluarganya, maka semakin besar pendapatan penghasilan wanita yang bekerja di lingkungan universitas di Yogyakarta memberikan keselarasan bagi kehidupan keluarganya. Dengan demikian, semakin tinggi pendapatan penghasilan bagi wanita yang bekerja, maka semakin baik tingkat keharmonisan dalam memanajemen hubungan keluarganya.

Manajemen waktu bagi wanita yang bekerja terhadap keselarasan keluarga, berdasarkan uji analisis regresi membuktikan $\beta_{3}=0,419 ; \mathrm{p}-0,000<0,05$, bahwa manajemen waktu memiliki pengaruh yang sangat signifikan terhadap keselarasan keluarga, menyatakan bahwa keselarasan keluarga dapat dijelaskan oleh manajemen waktu. Kepedulian wanita yang bekerja terhadap manajemen waktu sangat besar apalagi terhadap peraturan-peraturan yang berlaku di instansi atau universitas bahwa manajemen yang baik bagi wanita yang bekerja dapat menumbuhkan perkembangan bagi instansinya serta dapat memberikan waktu untuk keharmonisan keluarga, maka semakin baik wanita yang bekerja menempatkan waktu pada tempatnya, semakin baik pula tingkat kinerjanya terhadap instansi dan juga dapat membagi waktunya untuk keselarasan keluarga.

Latar belakang pendidikan, pendapatan, dan manajemen waktu wanita yang berkerja secara bersama-sama memiliki pengaruh yang signifikan terhadap keselarasan keluarga $\left(\mathrm{R}_{y, 123}=0,624 ; \mathrm{F}=\right.$ 24,693; $\mathrm{p}=0,000<0,05)$ dengan sumbangan sebesar 39\%. Membuktikan bahwa keselarasan keluarga dapat dijelaskan oleh latar belakang pendidikan, pendapatan, dan manajemen waktu bagi wanita yang berkerja di universitas. Dengan demikian, keselarasan keluarga bagi wanita yang bekerja sangatlah penting dalam kehidupan rumah tangga, bahwa keselarasan keluarga mempunyai arti penting bagi kehidupan rumah tangga, di sampmg itu pendidikan yang tinggi juga dapat memberikan pengertian dan pemahaman tentang keselarasan keluarga dan juga mengerti bagaimana dapat meinecahkan masalah-masalah dalam keluarga yang baik.

\section{DAFTAR PUSTAKA}

Bryson's. (2004). Strategic Planning in Public and Nonprofit Organizations. Manfredo and Associates. Diambil pada tanggal 07 Juli 2004, dan http: Ilwww.manfredo. biz/strategic\%2Oplanning\%primer.htm. 
Hadisupadmo. (1988). Mobilitas Penduduk Non Materi Batik. Yogyakarta: UGM. HR. Bukhori. (1999). Peran Ganda Wanita Modern, Jakarta: CV Pustaka Alkamar. Ihromi T.O. (1999). Bunga Rampai Sosiologi Keluarga. Jakarta: Yayasan Obor.

Irsyad Syafar Buan. (2000). Orientasi Pembaharuan Pendidikan dalam Tantangan Modernitas: Jurnal OASE edisi 16. Diambil pada tanggal 01 Juni 2003, dan http://jumal/tentangoase/isnet.org/pdk.htm.

Mumi, Sri Puspita. (2000). Pendidikan Pancasila dan Kewarganegaraan. Jakarta: Bumi Aksara.

Saidihardjo. (1997). Jati Diri, Sumber Daya Manusia dan Tantangan Pendidikan pada Era Globalisasi. Makalah Seminar dan Sarasehan Forum Komunikasi VII Pimpinan FPIPS/PIPS se-Indonesia di Universitas Negeri Yogyakarta.

Sudibla, LK. (1985). Mobilitas Penduduk dan Sumbangan Pendapatan Rumah Tangga di Daerah Asal; (Studi Kasus di Desa Menggi Kabupaten Badung Bali). Tesis Master, tidak dipublikasikan, Universitas Gadjah Mada Yogyakarta.

Timpe, Dalle (1987). Senillmu dan Sent Manajemen Bisnis Mengelola Waktu, Jakarta: Gramedia 